\title{
Effect of Bullying on the Adjustment Patterns of Higher Secondary Students
}

\author{
Ramaprabou. $\mathrm{V}^{1 *}$
}

\section{ABSTRACT}

The present investigation was undertaken to study the effect of bullying behaviour and victimization on adjustment patterns of higher secondary students. For this 75 students studying in various higher secondary schools of Puducherry were approached randomly using convenient sampling method. Adjustment Inventory for School Students constructed and standardized by Sinha and Singh (1995) and Illinois Bully Scale developed and standardized by Espelage and Holt (2001) was used for data collection. Analysis was done by using one-way ANOVA. Findings of the study revealed that bullying and victimization has significant effect on the adjustment patterns of the students.

Keywords: Bullying, Victim, Adjustment, Higher Secondary Students

Bullying is an intentional act of humiliating and embarrassing an individual to demoralize them. At lighter levels people take that as a general comment on their behaviour. When it is being intentional, repeated and made beyond the tolerance level of the victim, it becomes an offense. Olweus Dan (1990) states that a person is being bullied when he or she is exposed repeatedly and over time to negative actions on the part of one or more other persons. Bullying is found among almost all irrespective of their age, class and status. Most of the times the causes for this kind of bullying will be the comparison of the individual with others about their way of living, dressing, and other things or properties they use. Sometimes bullying is done in the name of 'making a joke' about the physical look or labelling the other individual with distinctive names. According to McGraw (2008), "Bullies aims at things about others that makes them distinct from others, whether it is their clothes, their voice, skin colour, body weight or anything else”. A study conducted by Ramya, Murlidhar Kulkarni (2011) reported that $60.4 \%$ of the 500 children are having the commonest forms of bullying like calling with nick names and making fun of one's looks.

\footnotetext{
${ }^{1}$ Assistant Professor of Psychology, Tagore Arts College, Puducherry, India *Responding Author

Received: January 18, 2017; Revision Received: February 9, 2017; Accepted: February 15, 2017 (C) 2017 Ramaprabou V; licensee IJIP. This is an Open Access Research distributed under the terms of the Creative Commons Attribution License (www.creativecommons.org/licenses/by/2.0), which permits unrestricted use, distribution, and reproduction in any Medium, provided the original work is properly cited.
} 


\section{Effect of Bullying on the Adjustment Patterns of Higher Secondary Students}

Bullying is a kind of aggressive behaviour found among peers that often occurs in schools (Smith et al., 2000) and it was found more in the form of quarrels, taunting and rivalry. Often this leads to psychological problems like anxiety, low self-esteem, poor self-concept and adjustment problems among the students. Bullying and victimization was widespread among the Indian school going youth (Malhi et al., 2004). In a survey the American Psychological Association, reported that "40\% to $80 \%$ of children are bullied at some point during their school days" (Graham Sandra, 2012). A study conducted by Harris \&Hathorn (2006)reports that bullying at school often creates a barrier for young people to develop into well-adjusted adults. Further many research studies proved that bullying and victimization cause varying extent of damage to the psychosocial wellbeing of children (Olweus, 1996; Ozdemir\&Stattin, 2011; Pellegrini, Bartini, \& Brooks, 1999; Veenstra et al., 2005).

\section{Objective}

1. To study the effect of bullying behaviour and victimization to bullying on adjustment patterns of Higher Secondary School students.

\section{Hypothesis}

1. Higher Secondary School students do not differ in adjustment patterns on the basis of their bullying behaviour and victimization to bullying.

\section{METHOD}

\section{Population}

The study was conducted among 75 higher secondary school students who have been identified as mischievous by their classmates and school teachers studying in various schools functioning in and around Union Territory of Puducherry. Convenient sampling method was used for collecting the data. The data were collected individually from the students through questionnaire.

\section{Tools Used}

Adjustment Inventory for School Students constructed and standardized by Sinha and Singh (1995) was used to measure the adjustment level of the students. The inventory contains 60 items which are equally distributed amongst the three areas of adjustment like Emotional adjustment, Social adjustment and Educational adjustment. High score in any given area of adjustment indicates poor adjustment and low score indicates healthy adjustment. The scale has reliability coefficient of 0.95 (split half) and hence used in its original form.

The Illinois Bully Scale developed and standardized by Espelage and Holt (2001) was used to measure the bullying behaviour of the students. The scale has 18 items with three subscales namely Victim subscale, Bully subscale and Fight subscale. For the present study only the victimization and bullying subscales are used. Higher the score in a subscale indicates more victimization and more bully preparation. The scale found to have a good validity and 
reliability value (Cronbach's alpha $=0.88$ ) and hence used in its original form to collect the data.

\section{RESULTS AND DISCUSSION}

Table No.1 showing the adjustment patterns of Higher Secondary School Students on the basis of their victimization to bullying.

\begin{tabular}{|c|c|c|c|c|c|c|c|}
\hline \multicolumn{2}{|c|}{ Variables } & $\mathbf{N}$ & Mean & $\begin{array}{c}\text { Std. } \\
\text { Deviation }\end{array}$ & $\begin{array}{l}\text { Std. } \\
\text { Error }\end{array}$ & $\mathbf{F}$ & Sig \\
\hline \multirow{3}{*}{$\begin{array}{l}\text { Emotional } \\
\text { Adjustment }\end{array}$} & Mild Victim & 10 & 4.10 & 1.101 & .348 & \multirow{3}{*}{35.75} & \multirow{3}{*}{.001} \\
\hline & Moderate Victim & 22 & 4.59 & 1.623 & .346 & & \\
\hline & Severe Victim & 43 & 7.30 & 1.440 & .220 & & \\
\hline \multirow{3}{*}{$\begin{array}{l}\text { Social } \\
\text { Adjustment }\end{array}$} & Mild Victim & 10 & 4.90 & 1.663 & .526 & \multirow{3}{*}{7.13} & \multirow{3}{*}{.001} \\
\hline & Moderate Victim & 22 & 5.41 & 1.403 & .299 & & \\
\hline & Severe Victim & 43 & 6.40 & 1.237 & .189 & & \\
\hline \multirow{3}{*}{$\begin{array}{l}\text { Educational } \\
\text { Adjustment }\end{array}$} & Mild Victim & 10 & 4.20 & 1.317 & .416 & \multirow{3}{*}{8.21} & \multirow{3}{*}{.001} \\
\hline & Moderate Victim & 22 & 4.27 & 1.667 & .355 & & \\
\hline & Severe Victim & 43 & 5.79 & 1.670 & .255 & & \\
\hline
\end{tabular}

It is observed from the Table No.1 that the mean scores of mild victims for emotional adjustment is less (4.10) than Moderate victims (4.59) and Severe victims (7.30). This shows that students who become occasional or mild victims show good emotional adjustment. Whereas the students who become moderate victim show average emotional adjustment and the students who are victimized severely for bullying show unsatisfactory emotional adjustment. The difference between the groups was also established by the obtained $\mathrm{F}$ value which is statistically significant at 0.001 levels. Hence it may be concluded that amount of victimization to bullying do have effects on the emotional adjustment of the school students. Several research studies are also proved that bullying at school has repeatedly shown victimized students exhibit poor psychological adjustment (Alsaker \& Olweus, 1992; Juvonen, Nishina, \& Graham, 2000; Kupersmidt, Coie, \& Dodge, 1990).

In a study Raskauskas \& Stoltz (2007), reported that victims of bullying found to have poor psychosocial adjustment. The present investigation proved that students who are victimized for bullying at mild levels show good social adjustment (4.90) than those who are victimized to a moderate level (5.41) and severe level (6.40). This shows that students who experience less bullying do have good social adjustment than students who became moderately victimized and severely victimized. These students show an average social adjustment. The difference between the mean scores was also established by the obtained F value (7.13) which is statistically significant at 0.001 levels. Hence it may be concluded that amount of victimization to bullying do have effects on the social adjustment of the school students. 
It is also seen from the above table that students who are victimized for bullying at mild levels show good Educational adjustment (4.20) than those who are victimized to a moderate level (4.27) and severe level (5.79). This shows that students who experience less bullying do have good educational adjustment than students who became moderately victimized and severely victimized. These students show an average educational adjustment. The difference between the mean scores was also established by the obtained $F$ value (8.21) which is statistically significant at 0.001 level. Hence it may be concluded that amount of victimization to bullying do have effects on the educational adjustment of the school students. Many research studies are of the view that Bully-victims seem to have poor performance concerning school achievement and peer interactions (Cook, Williams, Guerra, Kim, \&Sadek, 2010; Nansel, Craig, Overpeck, Saluja, \& Ruan, 2004; Veenstra et al., 2005).

Table No.2 showing the adjustment patterns of Higher Secondary School Students on the basis of their level of bullying behaviour.

\begin{tabular}{|c|c|c|c|c|c|c|c|}
\hline \multicolumn{2}{|c|}{ Variables } & $\mathbf{N}$ & Mean & $\begin{array}{c}\text { Std. } \\
\text { Deviation }\end{array}$ & $\begin{array}{l}\text { Std. } \\
\text { Error }\end{array}$ & $\mathbf{F}$ & LS \\
\hline \multirow{3}{*}{$\begin{array}{l}\text { Emotional } \\
\text { Adjustment }\end{array}$} & Mild Bully & 12 & 5.67 & 1.614 & .466 & \multirow{3}{*}{2.98} & \multirow{3}{*}{.05} \\
\hline & Moderate Bully & 37 & 5.68 & 2.249 & .370 & & \\
\hline & Severe Bully & 26 & 6.85 & 1.690 & .331 & & \\
\hline \multirow{3}{*}{$\begin{array}{l}\text { Social } \\
\text { Adjustment }\end{array}$} & Mild Bully & 12 & 4.83 & 1.337 & .386 & \multirow{3}{*}{9.80} & \multirow{3}{*}{.001} \\
\hline & Moderate Bully & 37 & 5.68 & 1.435 & .236 & & \\
\hline & Severe Bully & 26 & 6.73 & 1.079 & .212 & & \\
\hline \multirow{3}{*}{$\begin{array}{l}\text { Educational } \\
\text { Adjustment }\end{array}$} & Mild Bully & 12 & 5.08 & 1.782 & .514 & \multirow{3}{*}{.89} & \multirow{3}{*}{ NS } \\
\hline & Moderate Bully & 37 & 4.89 & 1.612 & .265 & & \\
\hline & Severe Bully & 26 & 5.50 & 2.005 & .393 & & \\
\hline
\end{tabular}

It is observed from the Table No.2 that the mean scores of the students who domild level bullying for emotional adjustment is less (5.67) than Moderate bullies (5.68) and Severe bullies (6.85). This shows that students who do bullying occasionally or at mild levels do not have any emotional disturbances and show good emotional adjustment. Whereas the students who do bullying at moderate level show average emotional adjustment and the students who do bullying at severe level show unsatisfactory emotional adjustment. The difference between the groups was also established by the obtained $\mathrm{F}$ value (2.98) which is statistically significant at 0.05 levels. Hence it may be concluded that amount of bullying behaviour do have effects on the emotional adjustment of the school students. The same is supported by a research study made by (Nansel et. al., 2001) states that the youths who do bullying and being bullied show very poor social and emotional adjustment. 


\section{Effect of Bullying on the Adjustment Patterns of Higher Secondary Students}

It is evident from the above table that students who do mild level bullying show good social adjustment (4.83) than those who do moderate level bullying (5.68) and severe level bullying (6.73). This shows that students who do mild bullying have good social adjustment than students who do moderate bullying and severely bullying. These students show an average social adjustment. The difference between the mean scores was also established by the obtained $\mathrm{F}$ value (9.80) which is statistically significant at 0.001 levels. Hence it may be concluded that amount of bullying behaviour do have effects on the social adjustment of the school students.

In a study Sarah Woods and Dieter Wolke (2004), proved that bullying often lead to poor academic achievement. The present study also portrays that those students who do bullying mildly show good Educational adjustment (5.08) than those who are bullied moderately (4.89) and severely (5.50). This shows that students who experience less bullying do have good educational adjustment than students who do moderate bullying and severe bullying. These students show an average educational adjustment. But the difference between the mean scores was not established by the obtained F value (0.89) which is not statistically significant. Hence it may be concluded that amount of bullying behaviour do not have much affects on the educational adjustment of the school students.

\section{CONCLUSION}

From the results it may be concluded that the students who are bullies and victims of bullying do have significant differences in their adjustment patterns. However, students who do mild bullying and victimized to less bullying tend to show a consistent stable emotion, submissive and interest in curricular and co-curricular programmes. The students who do severe bullying and those who are highly victimized for bullying show unstable emotion, aggressive behaviour and poor adjustment with curricular and co-curricular programmes.

\section{Acknowledgments}

The author appreciates all those who participated in the study and helped to facilitate the research process.

Conflict of Interests: The author declared no conflict of interests.

\section{REFERENCES}

Alsaker, F.D., and Olweus, D. (1992). Parental relationships, peer relationships, and the development of depressive tendencies in adolescence. Paper presented at the biennial meeting of the Society for Research on Adolescence, Washington, DC.

Cook, C. R., Williams, K. R., Guerra, N. G., Kim, T. E., \&Sadek, S. (2010). Predictors of bullying and victimization in childhood and adolescence: A meta-analytic investigation. School Psychology Quarterly, 25(2), 65-83. 


\section{Effect of Bullying on the Adjustment Patterns of Higher Secondary Students}

Espelage, D. L., and Holt, M. (2001). Bullying and victimization during early adolescence: Peer influences and psychosocial correlates. Journal of Emotional Abuse, 2, 123-142.

Graham,Sandra, (2012). "Bullying: A Module for Teachers". American Psychological Association, Retrieved 12-30.

Harris, S. \&Hathorn, C. (2006). Texas middle school principals' perceptions of bullying on campus. NASSP Bulletin, 90 (1) 49-69.

Juvonen, J., Nishina, A., \& Graham, S. (2000). Peer harassment, psychological adjustment, and school functioning in early adolescence. Journal of Educational Psychology, 92, 349359.

Khezri, H. EbrahimiGhavam, S. Mofidi, F. Delavar, A. (2013). A Bullying and Victimization: Prevalence and Gender Differences in a Sample of Iranian Middle School Students. Journal of Educational and Management Studies, 3(3): 224-229.

Kupersmidt, J.B., Coie, J.D., and Dodge, K.A. (1990). Predicting disorder from peer social problems. In S.R. Asher \& J.D. Coie (Eds.), Peer rejection in childhood (pp. 274-305). New York: Cambridge University Press.

Malhi, P., Bharti, B. and Sidhu, M. (2004). Aggression in Schools: Psychosocial Outcomes of Bullying Among Indian Adolescents. Indian Journal of Pediatrics, Volume 81, Issue 11, pp 1171-1176. Doi:10.1007/s12098-014-1378-7.

McGraw, J. (2008). Life Strategies for Dealing with Bullies. Aladdin, New York.

Nansel TR, Overpeck M, Pilla RS, Ruan WJ, Simons-Morton B, Scheidt P. (2001). Bullying Behaviours Among US Youth Prevalence and Association with Psychosocial Adjustment. JAMA, 285(16):2094-2100. doi:10.1001/jama.285.16.2094.

Nansel, T. R., Craig, W. M., Overpeck, M. D., Saluja, G., \& Ruan, W. J. (2004). Cross-national consistency in the relationship between bullying behaviours and psychosocial adjustment. Archives of Pediatrics \& Adolescent Medicine, 158(8), 730-736.

Olweus Dan, (1990). Bullying among School Children. Chapter 13, In Health Hazards in Adolescence by Klaus Hurrelmann and Friedrich Losel, Walter de Gruyter, New York.

Olweus, D. (1996). Bully/victim problems at school: Facts and effective intervention. Reclaiming Children and Youth, 5(1), 15-20.

Ozdemir, M., \&Stattin, H. (2011). Bullies, victims, and bully-victims: A longitudinal examination of the effects of bullying victimization experiences on youth wellbeing. Journal of Aggression, Conflict and Peace Research, 3(2), 97-102.

Pellegrini, A. D., Bartini, M., \& Brooks, F. (1999). School bullies, victims, and aggressive victims: Factors relating to group affiliation and victimization in early adolescence. Journal of Educational Psychology, 91(2), 216-224. http://doi.org/10.1037/00220663.91.2.216

Ramya S. G., Murlidhar L. Kulkarni (2011). Bullying Among School Children: Prevalence and Association with common symptoms in Childhood. The Indian Journal of Paediatrics, Volume 78, Issue 3, pp 307-310. 


\section{Effect of Bullying on the Adjustment Patterns of Higher Secondary Students}

Raskauskas, J., \& Stoltz, A. D. (2007). Involvement in traditional and electronic bullying among adolescents. Developmental Psychology, 43, 564-575.

Sarah Woods and Dieter Wolke (2004). Direct and relational bullying among primary school children and academic achievement. Journal of School Psychology, Volume 42, Issue 2, March - April 2004, Pages 135 - 155.

Sinha, A.K.P and Singh, R.P. (1995). Adjustment Inventory for School Students. National Psychological Corporation, Agra.

Smith, P.K., Brain, B.F. (2000). Bullying in the school. Aggressive Behaviour, 26(1), 1222-1232.

Veenstra, R., Lindenberg, S., Oldehinkel, A. J., De Winter, A. F., Verhulst, F. C., \& Ormel, J. (2005). Bullying and victimization in elementary schools: A comparison of bullies, victims, bully/victims, and uninvolved preadolescents. Developmental Psychology, 41(4), 672-682.

How to cite this article: Ramaprabou V (2017), Effect of Bullying on the Adjustment Patterns of Higher Secondary Students, International Journal of Indian Psychology, Volume 4, Issue 2, No. 89, ISSN:2348-5396 (e), ISSN:2349-3429 (p), DIP:18.01.084/20170402, ISBN:978-1-365$74162-3$ 